\title{
Research on Marx's love thought and Its Contemporary Value
}

\author{
Zhijian $\mathrm{Yu}^{1, \mathrm{a}}$ \\ ${ }^{1}$ School of economics and management, Beijing University of Posts and Telecommunications, \\ Beijing10000, China; \\ a731884099@qq.com
}

Keywords: Marx's thoughts, college students, view point of love.

\begin{abstract}
Marx in his classic book using dialectical materialism and historical materialism, scientific method and its related to the love question has carried on the thorough analysis, and put forward many insightful views. Never go out of style, of the Marxist theory in the new historical period, Marxism has been endowed with new connotation. This article is based on the analysis of college students' status and Marxism in love, applying the idea of Marx's love of contemporary college students to establish correct love, make guidance, fully develop its contemporary value.
\end{abstract}

\section{Introduction}

One of the most important contents of contemporary college students' life is love, with the growth of age, college students begin to think about love, and gradually form different views of love. In real life, the correct understanding of the nature of love, deal with the relationship between love, love will bring happiness to life. College positive youth, establish a correct outlook on love, deal with complex emotional and interpersonal relationship, is conducive to the healthy growth of college students success. Marx's materialistic view of love, as a scientific view of love, has a good guiding role for the contemporary college students' view of love.

\section{Marx's thought of love}

In the view of Marx: "love is a pair of men and women certain social foundation and the common ideal of life based on the formation of mutual admiration, and desire for the other to become a strong and pure, the feelings of his life partner in their hearts. Sex, ideal and responsibility are the three basic elements of love." [1] Here, Marx and Engels from the instinct of human nature, social nature, physical and mental development, and in combination with the concept of marriage and family values are introduced in view of love, to provide scientific theoretical basis for the research on Contemporary College Students' view of love.

So, what is the correct view of love? The author thinks that the correct view of love must be able to correctly reflect the basic requirements of love, according to the above theory of Marx s concept of love can be described summed up the correct view of love should be showed the following characteristics:

\subsection{With like-minded as the premise}

Love is mutual love first, for love between the two sides of thought the same, spiritual resonance, and this "consistency" and "resonance" requirement each with similar or even the same world outlook, outlook on life and values, have a consistent attitude to life, have the same ideals and aspirations and interests. As the saying goes "Like attracts like.," different Birds of a feather flock together. ", now" this is a true portrayal of interpersonal relationship, people will always be preferred and their consistent person communication and to establish friendly relations.

\subsection{To loyalty based}

Love has its own exclusive exclusiveness, which requires both sides to be loyal and faithful to each other. At the same time, love can only be given to the same person. Any "Have a foot in two camp", "affair" is on the other side of the feelings are not specific, any concealment and deception, "one night stand" on the other side are not loyal. Love is not loyal, not single-minded behavior is 
bound to bring pain to each other, and even the breakdown of love relationships. Mr. Tao Xingzhi compares love to wine for this: "the wine of love, sweet and bitter. Two people drink, is nectar. Three people drink, sour as vinegar. Drink, poison." [2]Therefore, a correct view of love for both men and women to withstand the test of time, the temptation of the outside world, the vicissitudes of life and other factors in the love relationship, always put feelings in the selection of the body, no more emotional shift of two minds.

\subsection{With respect as the core}

Love is enduring and requires love both sides of love, a continuation and development and continuous efforts, it is in the understanding of each other, each stage of love, marriage and family in mutual respect, mutual help, mutual responsibility. Only in this way, the relationship can be carried out smoothly and develop. Respect for the highest moral requirements of love, but also the essence of love. Any disrespect behavior will cause the other side of the offensive, any irresponsible behavior will be condemned. Respect for each other's identity values of life, personality, habits and living space, rather than blindly stand on our own point of view, to use their own ideas to judge each other, and even accused the other of denying each other, respect each other to achieve mutual understanding, tolerance, harmony, love to sustainable development.

\subsection{Marriage and family as the goal}

Love is pure, requires both sides of love motivation simple, correct attitude, a correct understanding of the relationship between love and marriage and family in the future. True love is bound to each other through acquaintance, friend, love, be accompanied by the process, is also recognized by both sides by understanding, love to marriage and family. Love and marriage are two core stages of love generation and development, and the two are directly related, even a progressive relationship. So, to love and marriage and family relations for the purpose to choose a spouse, not simply because I want to love and to love, to love as life experience and interpersonal relationship in a simple, ignore the inevitable result of love.

\subsection{The principle of social ethics}

Love is social, people always exist as a social person, so all human behavior is regulated and restricted by social morality. Love is a kind of special interpersonal relationship, it is not only the love of both men and women, but also to other people and social influence, so it is bound by social morality. The correct view of love is in the social level, which requires that the behavior of both men and women should conform to the social norms, behave appropriately, and do not have the immoral behavior of the public and social environment. Love is emotional, but love behavior must be rational, excessive exposure and irrational intimacy and propriety cannot make people really feel the love that a shy, introverted beauty. As Marx said, "true love is implicit, to take his idol in lover's modest, even shy, not in a casual performance with love and intimacy premature." [3]Therefore, the correct view of love is bound to require both men and women consciously abide by social morality, with its basic behavior standards.

\section{3. with Marx's thought of love to guide college students}

\subsection{A correct concept of love, respect for equality of personality}

Marx pointed out: "the modern monogamous family, is a product of historical development, he will be with the development of society and achieve a more advanced stage, moral characteristics at that stage, will be to achieve real equality between sexes."[4] Engels pointed out that only monogamy can develop the greatest moral progress, and only be wiped out in the system of exploitation, human beings can achieve real monogamy and equality between men and women, the marriage based on love is possible and reach a higher level. Engels pointed out: "love is the premise of mutual love." [5]This is the embodiment of love equivalence, but also the equality between men and women love each other constitute an important condition for happiness and love. Between lovers of independence and respect each other's equal status, if regard each other as their vassals, or too dependent on each other, will lose the meaning of love. Education "post-90" college students in the process of love, not only to respect each other's personality, but also to maintain their own personality, fully believe that lovers, respect for lovers. 


\subsection{Establish a correct concept of mate choice}

A model of Marx and Yan Ni's marriage love is faithful. Jenny was born to a wealthy family, this can have a wonderful life in society. And Yan Ni in the period of love with Marx, a lack of all of the family poverty, but has a heart of hard work, there is a deep love for the love of Yan Ni Marx. Jenny can choose him, although Marx's life wandering was removed, living in poverty, experienced difficulties of ordinary people cannot imagine hard, however as his wife Jenny never abandon, with their true to the core, a broad mind to encourage and support her husband's career, bear the hardships of life and selfless. This is a great example for us. In contrast, the "post-90" college students pay too much attention to the material foundation, the deliberate pursuit of "equal", many people hope that through the fate of life mate change, "the two generation" and "two rich generation" has become a popular candidate and sought after resources. As everyone knows, too much emphasis on material marriage will be buried in the future of marriage. We must implement the correct choice of "post-90" college education, the "post-90" students to recognize in the lover of choice, should pay attention to morality, knowledge, physical appearance, personal qualities, the ideological and moral, consider other aspects, but also to take into account. Everyone's situation is different, cannot compare with each other, we must proceed from their actual situation, will be good at all aspects of the comprehensive analysis, the main distinction between what is and what is secondary, what is not necessary, "Every bean has its black." to "catch down", "seek differences in" common ideals and goals consistent with the premise, mutual tolerance, mutual understanding, mutual respect, common progress.

\subsection{Intentions management, civilized love}

Love is the embodiment of civilization of love between the two sides implicit, courteous, friendly and even shy attitude. This is a kind of elegant, mysterious, subtle emotional world, but also the embodiment of personal good self-cultivation. And not by any means, excessive display, indulgent attitude. Lovers in public places, to comply with the minimum social morality, pay attention to their language behavior, which is the respect and love of the lovers. At the same time, we should also realize that not only the love is not good for the dignity of love, it is more likely to cause the vulgarization of love, but also hurt the social atmosphere. Marx pointed out: "in love, too familiar rude way beyond the indecent behavior stage, are lack of moral performance. Only when the emotion of reason and love can be truly integrated, can we make a beautiful and beautiful love song."[6] Love is a part of life, no one can go on the road of love. To the education of post-90s college students correctly deal with emotional problems, once the emotional problems, to find classmates, friends, parents and teachers are talking, listen to their views, can also use the words of their own unhappiness and anger experience all recorded, as a way to vent, to shift their attention, establish the new points of interest. Take part in group activities, develop their own interests, which is one of the best ways to solve the problem of love. Shakespeare said: "the destruction of love, once established, will be more magnificent, more beautiful, more tenacious than the original."[7] Only in this way, when Cupid shot again when the fruit of love will feel more sweet.

\section{Acknowledgments}

This work was financially supported by Research Innovation Fund for College Students of Beijing University of Posts and Telecommunications, number971;

\section{References}

[1] Marx, Engels, ideological and moral cultivation and the legal basis of [M], higher education press, 2008134.

[2] Fang Ming. Tao Xingzhi complete works [M] Sichuan: Sichuan Education Press, 1982: 32.

[3] "Marx Engels collection" volume twenty-first [M]. Beijing: People's publishing house, 1965: 97. 
[4] Marx, Engels, Marx "Engels anthology", volume third [M], Beijing people's publishing house, 1995, page 213.

[5] Engels, the "family, private ownership and state of origin", Engels people's Publishing House in 1965 version, page eighty-seventh.

[6] Marx, Engels, "Marx Engels collection" twenty-first volumes, Beijing people's publishing house, 1965 Edition.

[7] [UK]Shakespeare, "Sonnets". 